\title{
From Deep Space: The Poetry of Robert Dana Edward Brunner
}

IF ONE ATTENDS primarily to the brisk, clipped tone that sounds frequently in Robert Dana's What I Think I Know (new poems, with a selection from his four previous volumes plus a number of uncollected works from the 1950s) one might conclude that Dana descends from the long line of street-tough poets-sharp, brusque, guarded-that originated with Villon and extends now to Philip Levine, C. K. Williams, and Raymond Carver. For such poets, the urban setting supplies a backdrop of random violence against which they must define themselves. Their essential problem is whether anything like tenderness can be sustained in so hostile an environment. Often their solution is to recall a moment of fragility or vulnerability that emerged unexpectedly, despite violent circumstances. These poets deploy the poem as a guard or shield: the hard shell of their brusque voice serves to sequester that fragile moment, preserving it for always. And so Villon's poems naturally take the form of last wills and testaments, handing down gifts for posterity (even ironic gifts); and Levine's poems frequently return to adolescent days in Detroit, to a time when toughness and tenderness seemed opposite sides of the same coin.

Yet ultimately, Dana's work fits awkwardly alongside poems in the street-tough tradition. That tradition depends on plain speaking. A flat, next-to-prose discourse is useful because its very blankness alludes to the weight of the city streets, but also because it can easily be cast aside to redeem an instance by depicting it with special reverence. But the verbal surface of a Dana poem is apt to be unusually disrupted. Several voices contend for dominance in the middle of "Aquamarine":

We shell before breakfast, washing the morning's haul in the kitchen sink. Dull

Atlantic cockles mostly; a Baby's Ear; one perfect Lion's Paw; a few, small 
bright calicoes my sister wouldn't walk so far for, just as she won't sketch swimmers, or the jeweled hues of the blue crab I hold up for her by one of its bluetipped claws, or recall from deep space the years before my mother's death the voice I can't remember. "Those weren't nice times," she says.

Dana's meditative discourse lists evocative names that enliven a humdrum routine. But that is interrupted when his sister's presence exerts its authority. Dana holds names up for pleasure but not everyone will be appreciative. Others deny themselves pleasure, including the beauty of "blue- / tipped claws." His sister's prohibitions prevent recovering the one voice Dana would hear, an absence introduced by an unusually tangled syntax that replicates the "deep space the years." That precious voice is lost, while the voice we hear is its sheer opposite - the flat speech of his sister, pivoting on the inert word "nice." Her voice effectively duplicates an absolute border. And the lost voice is all the more haunting because the one who might hold a remnant of it within herself is so notoriously poor a judge of what is worthwhile.

Street-tough poets seek the bucolic in the urban - the tender moment that, while frail, is strong enough to counter the violence of the streets. Through such redemptive gestures, they promote order, or restore a temporary measure of civility. Dana inverts that characteristic trope: he finds the urban in the bucolic. The placid scene discloses marks of distress; the settled region is a grim frontier. Rather than promoting order, he would lower barriers. Instead of closing with a unifying gesture, he yearns to step beyond conventions to speak easily, intimately. The street-tough poets say we may think we are tough but we have great moments of tenderness. Dana says we may think we are fragile but we are tougher than we think. We can endure dislocation, the disruptions of loss; we should celebrate our resilience. 
In another deviation from the street-tough tradition, Dana's poems rarely unfold in urban settings. Their backdrop is usually a rural Midwest of farm fields and small towns. To be sure, these patchwork settings are hardly bucolic; they are, if anything, disheveled, half-finished, incomplete. Their haphazard features suggest misalliance. Not everything has worked out properly; untold stories and broken narratives lurk everywhere. In this disturbed area, the domesticating presence of the human may dwindle down to a few tidying gestures. Halfway through "Wichita" we are held in suspension, in the middle of nowhere:

Take a meadow abandoned to real estate; the real estate abandoned to grass and weed; the sky, zinc; the north wind, iron; and banging, sliding, down the shadows of wheel ruts, down the long double lane of trees that lead to no abandoned farmhouse, no tumbled foundations; the way just stopping dead at the swampy crossing where newer tracks cut through.

This is not Robert Bly's Midwest with its profound solitudes that sanction the inner life, nor James Wright's Midwest with its river town porches that offer the solace of a retreat. Dana's silences emerge as the deepest of spaces, and his weeds are tall enough to swallow a house. If anything, his Midwest resembles the slums and ghettos, the heedlessly dispersed segments of a once-prosperous city, where growth has been abrupt, disjointed, unplanned.

What seems hopelessly shattered, of course, may be only in need of the poet's attentive eye. But "Wichita" concludes unexpectedly:

There, we're left to do

what we can with the hawk

driven off by the crow, the couple 
of pines flanked south,

and the rosebush, run wild and

tough in the pale sun, flashing

rose hips bright as any petals.

You get all this like a slow post-

card from one of those tropical

countries, the view fixed

in one corner in the window

of the stamp: cheap, exotic, vivid.

For all his affection for this fallen world, Dana declines to redeem it. The hawk, the crow, the pines, the flowerless rosebush - these together make up no community. Yet the eye falls on them longingly, husbanding them with as much congeniality as can be mustered. Why the swerve toward a postcard? By swerving so, Dana recoils from his own impulse toward congeniality. Is he mocking his yearning for order, judging it as all too prim? (The stamp fixes its view neatly, as a window to gaze through.) Or is he taking subtle delight in his ability to look out upon a scene and savor the nothing that is there, to relish details others would overlook? (The vulgarity of the stamp's official view has its own sweep of energy.)

Dana's wonderfully improbable ending, with its colliding sets of divergent impressions, may draw attention away from the most obvious swerve he has taken: his shift to direct address, speaking straight to the reader. It is proper that this turn should be easiest to miss, however, for the lasting effect of this poem is to render the isolation of its setting, as well as the isolation of the poet. That isolation remains beyond transformation, as resistant to altering as the official version of a republic that circulates on a stamp. The poem's isolation commands the greatest authority; it cannot be broached. The poem revolves about it helplessly.

What is so unnerving about Dana's poetry is that it brings forward the very isolation it would overcome. The spaces in a Dana poem seem unusually vast because they are filled with missed connections. "A Short History of the Middle West" begins with a venerable analogy comparing the rolling land to the swell and surge of the ocean, "an ocean of dirt tilting and tipping." It is an appealing image, but what Dana understands is the human cost of living so close to this powerful force: 
Its towns

toss up on the distance, your distance

like the wink

of islands.

Towns are as cut off as islands. The pronouns tell: the towns are "its," the Midwest's, the ocean's, but the distances between them are "the distance, your distance," that gap opening between persons into which we fall. These gaps are filled unsubstantially - they are too consequential, their emptiness too profound:

Your neighbor

is out early this morning - the air

already humid as raw diamond.

Drunk or lonely, he's scattering large scraps of white bread for birds

as if it were winter.

He'd give you the sour undershirt off his back sweet, bad man.

Does he remember rain salting down from that flat, far shore of clouds

slowly changing

its story?

On this shore, the trees all babbling with their hands? 
The cost of living in isolation is that we never have a sure way to measure the propriety of another's gestures. Gestures seem either not informative enough or too excessive (like the line-lengths here, abruptly truncated or strung out very far). Is your neighbor "drunk or lonely"? Is he longing for winter or wishing for company? Does that "sweet, bad man" know? Is it his desire to befriend others or define himself defiantly?

Dana's Middle West has a "short history" because history here has not properly begun. Things still remain unfinished, and the distances between everything remain more noteworthy than any connections established. Yet such understanding points two ways. If one aspect of Dana's Midwest is its harrowing isolation, another is its exhilarating spaciousness. Both are evoked in the questioning mode that ends the poem. As inquiries that go unheard, Dana's questions register isolation; as broad gestures that escape fixed meanings but place the neighbor as part of the landscape, they express the poet's longings. Dana wants to end with something that is neither isolation nor spaciousness but a realm charged with positive obligations. Even if no contact is made, the poem makes such contact seem necessary, urgent and just out of reach.

Dana's poems expand as he recasts his sense of isolation into an occasion that prompts speech. Imagery in a Dana poem often counts for less than tone of voice. Most poems approach closure by drawing themes together, but a Dana poem signals its end when a voice emerges that is casual, unguarded, and directly addressed to a reader. The poem is complete, that is, when the poet can step outside the mechanics, the framework, the patterns of "the poetic" - and simply speak. For poets directly in the streettough tradition, the corresponding moment occurs when the city's violence recedes, giving way to an instant of recollected tenderness. But Dana's nemesis is isolation, not violence. Not tenderness but intimacy is in question.

For Dana, the poem is an opportunity for a rare intimacy, for a moment that fleetingly denies the isolation the poem otherwise displays. The title poem of Starting Out for the Difficult World displays the dilemma in the first of its two stanzas:

This morning, once again, I see young girls with 
their books and clarinets starting out for the difficult world. The wind has turned into the north. It picks a few leaves from the trees, leaves already curled, some brown. They scatter. Even so, their circles under maple and hackberry thicken. The light, clean as juice to the taste.

The young, frail students he views from afar have his sympathy. But they are also given what they do not need: his sorrow. Looking from a distance, he imagines them as indistinguishable from leaves that will be scattered. Only a few will succeed in the difficult world. Most will be left behind, as numerous as the leaves thickening in circles around the trees. In this melancholy, morose attitude, everyone is isolated and all are lost-especially the poet who observes this autumn ritual "once again," enduring the weight of the circles of time that have thickened around him.

But when Dana raises his eyes from the ground his poem takes a different turn:

Great art, someone said, rides on the backs of the poor.

Perhaps that's so. But this

is not Long Island. No packed

white waves leap yelping on the shore.

Here, the nights are cold and starry.

Three solitary clouds pig along

the near horizon. And you could

mistake this autumn for Keats's

or your own, or the

autumn of someone you once knew.

This is everything the first stanza was not. It draws in other voices to engage with them. It invokes poetic imagery only to mock its limitations 
(the "packed / white waves" that reduce oceanic energy to puppy's barks). It leads our eyes to an expansive horizon. And most important, it closes with an address almost like a whisper in its intimacy (the voice must pause, as though with a catch in the throat, in the hard cut between "the" and "autumn"). Yet the ending is wide-ranging and all-inclusive, in homage to the continuity of a season we all share and that links us through our memories.

Dana rides this momentum because he recoils from his melancholy, but he feeds his momentum because he would argue against elitism of any kind, either in poetry or in the success stories of those who appear to make it in the difficult world. He introduces the disturbing idea that great art "rides on the backs of the poor" only to turn that notion around: art has nothing to do with acts of elevation -it is not elevating but humbling to realize we are surrounded by that which extends so far beyond us. Great art makes us all seem poor, in comparison with its elemental power and authority. That is why poets who shape their ocean waves so delicately are simply mistaken: art has nothing to do with such shaping but everything to do with opening our eyes to where we are. The effect of Dana's ending depends heavily on the unsettling quality of "Three solitary clouds pig along / the near horizon." Is this a figure of abundance as the companionable clouds seem to bring the distant horizon near? Or a figure of isolation as the solitary clouds press along, absorbed in their passage by the edge of the sky? That these questions cannot be resolved allows Dana his final turn into a sense of autumn that includes the essential poetry of Keats, as well as one's own personal response, as well as the autumn that remains just beyond the grasp, on the edge of the horizon, like someone you once knew and now recall. Art should offer shared moments like this in which persons seem able to speak across immense vistas. It is the true difficult world in its indeterminate abundance. It cannot be reshaped and altered but remains palpable, like the light, available to all who look up. But it is not simply empowering; as much as anything, it is disempowering. It ravishes us with its endless possibilities, and it leaves us in a spaciousness greater than we could have believed.

In his recent poetry, Dana inhabits a large, jagged, contrary, threateningand-welcoming landscape scarred with the passage of previous survivors. 
But earlier, he felt differently enough to make a decision nearly fatal to his career. Instead of inhabiting his world in all its imperfect splendor, he set out to heal or redeem it. To do so, he had to keep his world small so it would remain manageable. When, after ten years of writing, he assembled his first book-length volume, Some Versions of Silence (1967), he favored a minimal verse, poetry shrunk to the smallest proportions, as if he could work with only one word at a time: "It is / whatever / it is; / binding us / like time / into time. / Mattering. / This room, our universe."

He widened his horizon in a sequence begun in his second book, The Power of the Visible (1971), and revised and completed as his third, In a Fugitive Season: A Sequence of Poems (1980). There, national politics intruded markedly, as it did for other poets in the 1970s. But at moments, his future subject appeared, if fleetingly:

I see that I am what I always was

That ordinary man on his front steps

bewildered under the bright mess of the heavens

by the fierce indistinguishable language of its stars.

He was not always able, in this sequence, to see himself so truly. Heavily in debt to the poetic diction of the 1970s - a style calling for the poet to act as a redemptive seer - he excoriated his country as a prophet while reshaping his own life along new principles. Almost every line is burdened with the need to display seismic change. The novelty required by this operates with punishing regularity.

In a Fugitive Season casts off its burden in a final group of London poems. Outside America, Dana also stands outside the ruling poetic discourse. As an exile he writes to others in exile: to Suetonius camped on the outskirts of the Roman Empire; to Blake as a perennial outsider (whose heritage lives on in graffiti); and to Duke Ellington, who did not have to leave his country to be in exile. The situation calls for a vernacular response. His London poems resemble letters; they dip into colloquial phrases, cite graffiti, and move as though improvised. The exile finds what he had been missing in the America he had been excoriating, and in his final poem, "Envoi, July 4th," he embraces an American landscape as humid and steamy as the English landscape had been frigid and gloomy: 
By dusk

all the pie has been eaten

flies sleep on the ceilings of heavy verandas

the day slows and softens

spear by spear

grasses burnt blonde

foxtail turn silver

disappear

In a way he had not allowed himself before, Dana relaxes into this work. Aggressive spears turn into leaves of grass and blur. In a Fugitive Season evolves through nearly a decade of change, and by its end it has worn out the language with which it began ("They lie under claws of light / who have been sentenced to their own names"). Its predictable novelties have been replaced by the unpredictable effects of close observation.

"Envoi, July 4th" is Dana's point of entry to his true poetic landscape. "Envoi" asks the poet to rest, to yield to the encroaching darkness, to see what still can be glimpsed in the final moments of a gathering dark. The poem could be taken as announcing his career was over: all the pie has been eaten, the long poem is done, the poet fades into oblivion. Instead, its quizzical, self-mocking air is the basis for a new beginning. All the pie has been eaten: at last the table is clear.

Dana's most recent work, like "Envoi," is both idiosyncratic and ordinary, both intensely poetic yet prose-like in its apparent modesty. Its artistry is deeply hidden because Dana wants the impression of a rambling, observational poetry that picks up anywhere, that sets itself in motion almost on a whim. $\mathrm{He}$ is fond, for example, of beginning with a gesture toward the chronicle, recording the time or conditions under which the poem begins. These openings seem so straightforward they could be prose statements typeset as lines of verse:

You come over a hill, suddenly

late afternoon or early evening on $6 \mathrm{~A}$ to Beach Point. 
Or: "The month is August, / but the day is October." Or: "Midsummer, and my neighbor's / cutting weeds in the dusk." Yet these openings deviate from the simplicity they evoke. The poem that sets out as a chronicle undermines simple chronology. It's late afternoon or early evening, and suddenly we're poised in time as we are in space when we crest a hill. Or it's August but feels like October. Or we're deep in summer except the moment is the transitional one of twilight. Cross-currents operate even in these offhand beginnings; the usual time is unusual. Appearing to be a "transparent" discourse that is neither poetry nor prose, the opening lines are already committed to eliding the very certainties they seem to reference.

$\mathrm{He}$ is also drawn toward producing small epiphanies, visions that occur on a modest scale. His poems could be mistaken for minute adjustments that seek balancing measures among extremes. What complicates that, however, is the lavish, extravagant weather that periodically floods a poem with enough force to bring it to a halt. Light is frequently the vehicle of that power: "the quick, / illimitable light," or "the light, clean as juice to the taste," or "A brilliant bush, tipped now / with clear light." But the weather is never far from any passage in one of his poems; it hovers nearby as a powerful, benign force that is apt to take sudden precedence:

\author{
Blue field. Great white \\ bison of cloud lugging their \\ easy humps. It's that kind \\ of day.
}

However it may appear, this extravagance of weather always occurs abruptly, as a disarming intervention, and it delivers the same message: it is too rich for us - how can we deserve it? It is more expansive than we can bear, so abundant it diminishes us. (Sunlight is especially voluptuous in poems that confess our most shameful actions: sunlight is never more glorious than in "At the Vietnam War Memorial, Washington, D.C.") Dana's epiphanic weather is small enough, a detail in passing, yet also too grand. Almost dislocating the poem, threatening to steer it off course, it serves as a reminder of Dana's urgent wish to step outside his very work. His weather cannot be resolved into something other than itself. And by 
returning us so vividly to the physicality of this world, it reminds us of the rewards of sheer, simple attention.

Dana's most persistent trait is a syntax organized around the sentence fragment. Long passages, whole stanzas, build from fragments, as though the poem were being dictated so rapidly only notes would do. But the final effect is not just spontaneity. These fragments hover precisely between the spare bones of prose and the deep currents of poetry:

The slender tongues of grass.

The clotted lips of stories

crumbled and tugged to humus.

Dirt of the soft bodies

of mothers, work-hardened

bodies of mothers, the roots

and twisted bodies of fathers.

Hands of a dead soldier.

You haven't come here for this.

As a narrative element, the sentence fragment points to a story told incompletely, its truncated syntax the very sign of a broken link. But just because the fragment defers full understanding, it also verges on its very opposite: the intense image folded upon itself with such density of meaning that its weight prevents it from opening into a complete sentence. Employing the sentence fragment in this double way, Dana is positioned to move toward the expansiveness of narrative or the density of images. He is free to lapse into passages impressionistic and descriptive, but just as free to move toward commentary and direct address.

Dana is actually chronicling the poem he is writing, the material that, juxtaposed in the order we have, generates momentum toward the conclusive moment when he can speak to the reader freely. A most felicitous example of this, "On the Beach at St. Augustine," begins:

Sanderlings. Turnstones. A lone willet. Fog-colors morning sun hasn't quite cut through. The still cold, grey-green March Atlantic rolling shoreward flank after glassy flank. 
Dana positions himself between notations that might be found in a journal and the complex associations that accompany a poem. The names of wading-birds, rich and strange as they sound, stand by themselves. But since these exotic names obscure the creatures they would recall (to the uninitiated they might be names of seashells), they lead toward observing fog in its different colors that the sun unsuccessfully cuts through. Why is the sun so weak? It is only March (there is Dana's chronicling gesture), and the ocean is a "cold, grey-green March / Atlantic" that rolls forward in flanks, like an army marching - and with the metaphor of invasion, the nomenclature of chronicling ("March") is retroactively elevated into poetic discourse. At the same time, of course, Dana is simply strolling on a foggy beach, early on a March morning, spotting seabirds.

In its careful description of St. Augustine, weaving memories of earlier visits, the poem seems remote from the Midwest. Then we learn:

The last time we came here in '79, Hurly'd just killed himself, blown his head open, back in Iowa, with his goddamned Smith \& Wesson, the brown corn stubble essing easy over the winter hills like the ancient Chinese character for river.

So the lavish attention paid to recording the moment has been a deliberate distraction. Unlike the erratic, shifting pace in other passages, these lines race by, one thought spilling rapidly, helplessly, into another. The contraction of Hurly's name (and the name itself) speeds up matters furtheruntil the passage slows into the soothing hills whose slopes suggest ancient civilizations. Cultivating land is associated with the sophisticated skill of calligraphy in sharp contrast to the business-like ampersand in "Smith \& Wesson" and the apostrophe clipping " '79."

Dana has been skirting this memory all along. And once this hidden detail is disclosed, he can ease into what is one of his gentlest passages - an extraordinary example of his desire to speak directly and freely to others, presented in a visionary context underscoring its rarity: 


\author{
Now, I no longer \\ believe we return as birds or fish \\ or even grit on the heave of the wind. \\ I think we were never anything \\ but what we are: the last, lovely \\ complex turn of it. And like \\ the planet, once, and for one \\ time only. Inventors of this \\ sea of cloud-struck afternoons, \\ of heat-haze, the happy dog \\ of the waves-walking at sunup \\ with other strangers this flat \\ reach of sand, and smiling \\ occasionally back at them \\ as we pass. Saying, occasionally, \\ "Good morning. Good morning."
}

Dana does not often permit himself such a graceful close. It may emerge here because its gentle ebullience is also being offered to those like Hurly, caught in the harshness of their frozen winter fields, unable to see the lifegiving grace in gentle undulations.

So harmonically deft an ending is, in one sense, untypical of Dana's recent work; he ordinarily steers clear of the imposing summary. But in another sense the ending is typical. Its final words are greetings, colloquial phrases spoken directly to others and including the reader. Dana's poems, strung together as a series of impressions, could be mistaken for the associations of the lyrical ego, an "I" that emphasizes its sensibility by hovering as a virtuoso between prose and poetry, the broken narrative and the dense image. That description, however, omits a striking trait. Nearly all his recent work at some point introduces someone who could center as the ideal audience for the poem under way: the neighbor feeding birds, or the students trudging to class, or Hurly. These people may not, within the poem, respond; they are not heard from. But the poem is for them. Not a sequence of mere associations, it is an interchange in which Dana's attention is gripped by another's presence; the poem is a space for an indirect transaction. 
These are fundamental, abiding concerns for Dana, evident from early writings produced under conditions not always congenial to expressions of intimacy. As a student in the Iowa Writers' Workshop (where his teachers were Robert Lowell and John Berryman, and his classmates included W. D. Snodgrass, Donald Justice, Philip Levine, Robert Mezey, Henri Coulette, and Jane Cooper), he mastered the high rhetoric that prevailed in the 1950s. But his approach even then favored direct speech, though within the grid of elaborate forms. "For Sister Mary Apolline" (first collected in his 1957 booklet $M y$ Glass Brother and later published in Poetry) achieves a level of excellence rare in the 1950s, though it was the standard to which all poets aspired. A sequence of six 10-line intricately rhymed (ABBCADCEDE) iambic pentameter stanzas, it is the first of Dana's awkward verse encounters with his half-sister, a sister grown into an institution herself by her acceptance of the nun's habit. Like W. D. Snodgrass's "Heart's Needle," Dana's poem frees itself from stifling conventions by employing a mode of direct address, so the work becomes the occasion for speaking to another who might not otherwise hear. For Snodgrass, the subject of his address, his daughter, is too young to understand his anguish (she is between three and five when the events of the poem occur), so he must curtail his speech in various ways. But Dana's subject, his sister as Sister, cannot hear because she chooses not to: to hear might be to open herself to such grief that she would be undone. Indeed, in one respect, she has already heard and is already undone: she has chosen to enter the world only by way of removing herself from it, to take on caring for all children instead of bearing her own. "When I called 'Sister' half the convent turned / And smiled." In transforming her own grief into a universalizing grief, by institutionalizing herself, she at once escapes her anguish and simultaneously guarantees it can never be escaped.

What makes Dana's poem so harrowing, though, is the way its stoptime implicates the poet. His sister's selfless care for other children is a reminder to her brother of the care withheld from him. At the center of the poem is this explanatory stanza whose autobiographical referents, while echoing Lowell's dramatic monologues in The Mills of the Kavanaughs, still breach 1950s decorum: 
Sister, we share no common heritage.

A son who does not wear his father's name,

My birth engendered all: the public shame

That rattled mother screwloose in her bed;

Your father, shattering in his rage

The sideboard glass, the radio and the clock;

Your trembling prayers, and your bowed head.

Above my crib dry birds of paper twirled,

And I, startled by the sounds, the shock,

Woke weeping in the dark and adult world.

The anguish in this poem is that the love his sister offers to the children on the convent playground, allowing them to grow with security, is the love that had been withheld from the speaker's own childhood. As evening falls the visit is complete, and Dana, at the time a Navy ensign, will return to his ship. The poem ends:

The bells, sound without reason,

Summon the sailor seaward, the nun to prayer.

Where there is time, time is its own reward.

We say goodbye. I turn and go, but stay

Fixed forever in your parting stare:

Eastward, the darkness that the doves are bringing;

But in the street, a boy prolongs his play,

Now murmuring to himself, now softly singing.

In this parting, which is at once a staying, the intervening years suddenly fold in, plunging the speaker back to that childhood where he never enjoyed that endless play. That is why he "prolongs his play" now, in this instant which expands, delaying the poem's end. The boy's play is noticeably muted-murmuring alternating with soft singing - turned inward, selfabsorbed, a form of self-caring made necessary by the absence of others (and perhaps evoked, inadvertently and sadly, by the lurking sternness in his sister's "parting stare"). This moment of intercession, in which an older Dana guards a younger, making a sheltering space in which that younger can flourish briefly, is the earliest instance of Dana's characteristic closing 
gesture in which the entire framework of the poem suddenly recedes under the poet's new-found ability to speak with intimacy, even if only to himself as a boy.

Dana's early work is a reminder of the severe and stringent standards poets beginning in the 1950s had to master. Direct speech gains an unusual value because it has to make its way across a formal grid. "Goodbye. Goodbye." (from My Glass Brother) is not only a farewell poem between lovers: it is also a Shakespearian sonnet. "For Lori My Daughter on Her Second Birthday" unfolds in four 8-line iambic trimeter stanzas. A companion poem to his son, "Late Fall Zinnias," follows the rules for endwords dictated by a sestina. In this poem, he admires tough-stemmed zinnias that "say 'no' / To the frost fallen." But his admiration is complicated by his tenderness toward his young son, whose fear of the dark draws him toward the late autumn evening fire where leaves are being raked and burned. His son is so young he knows only "Delight in snapping / Coals, a bright content." His father wants to turn his son's attention away from that glitter toward those flowers that endure despite the cold:

Praise these unfallen

Then, tough-stemmed, intent.

Pick, and hold them. No

Emblem is slight.

Roots are to hold by

When all else is snapping.

But his son has fallen asleep and cannot hear these words of strong advice. The father lifts his sleeping son, and this simple gesture becomes an act of helpless guardianship. The poem can only end with a moment of fragile beauty as sparks from the fire light on distant yards, "Firebirds on black snow." Nothing is rooted for long, everything is fated to be an ember, even the earth is snow, and the zinnias are doomed. There is no advice that saves, only the reaching and holding that temporarily protects. The tough wisdom lies in accepting that frailty.

Dana's inexorable movement, in his later free verse, toward direct address, toward speech that claims the reader's attention, is deeply rooted in his earliest work (much of which, previously uncollected, is now avail- 
able in What I Think I Know). "In the Gardens of Fabulous Desire" is a very recent extended meditation on what counts for community in our present surroundings. It begins with a swerve, allowing that we might prefer to avoid the experience entirely:

39, West of Hollandale, a sharp, backward curve and you miss it, the small house set in deep shade; lion and swan and tower rising from the burnt grass.

In giving directions that tell how to miss, not find, the house, Dana presents a setting we will be drawn to against our will. The deserted cottage he is about to describe will depict an uncomfortable scene (there are echoes of his childhood, he says, without elaborating upon them), but missing a scene is what we are most likely to feel at home with, staying on the move as we do. A glimpse from the road, a glance into that "deep shade," might be more than enough.

Dana's deserted cottage had been decorated extravagantly, "studded with bits of bottle / glass, pastel Fiestaware, / fragments of mirror." Meant to be seen, it is seen by no one. Even more dramatically, large cutout figures encircle it, a "Blond / Snow White," a "Viking / in his griffinpowered skiff," and others like the "lion and swan and tower" glimpsed from the road. The life-size creations remain both innocent and grotesque - not quite folk art, not quite pop icons. Most disturbing of all is their lavishness. So much energy expended, so much enterprise displayed, all for no audience, all in isolation. How much madness sprawls in this selfcontained place. Is it the inescapable truth that our desires ultimately turn "fabulous" - not just larger than life but distorted, like cartoon cutoutsbecause they remain held within our self-enclosed "gardens"? Thus all is a ruin even as it remains oddly intact, like frozen feelings, lost dreams, or unfinished narratives.

In one sense, this garden of desire, this lost museum, this fantasy playset, is the artist's nightmare. It represents the painting unviewed, the poem unread-lost from sight, grown monstrous in its neglect. But the true subject of this poem is the isolation that drives someone to express desire even 
as that desire is distorted in expression. Overcoming such isolation energizes Dana's conclusion:

\author{
What \\ are our calloused hands, \\ leaky bladders and bad backs, \\ but drunken song? Our ruined \\ faces, but work. And you \\ may think if you could get \\ the words to ring down \\ right, like Neptune's Wheel, \\ noun, verb; noun, verb; \\ the clown under his pointed \\ cap, the owl, the boy reading, \\ noun, verb-this whole \\ Calliope of crumbling dream \\ would wheeze again, whirl \\ and sing in the wild heat \\ and stagger of these weeds.
}

Dana's apostrophe is not simply a direction for praxis but an anguished expression that implicates all, including the poet, in the failure to understand others enough. He turns the situation inside out. The cutouts and decorations first seemed the products of an eccentric driven to create a world apart. But Dana insists we all occupy that eccentric position. By the decisions we make we shape our bodies; with the work we do we line our faces. If everyone could see that in each other, then our desires would no longer be "fabulous," freed as they would be from their self-enclosed gardens. To break through the surfaces that divide us from each other would be to overwhelm the isolation, restore dreams that are lost. Dana's poem ends, characteristically, by bringing us to the point where we might turn from the experience of the poem and begin to experience the poem in our lives.

Are gardens to be restored and broken narratives to be resumed? Perhaps Dana's sensitivity to gaps and omissions originates in the calamities of his childhood. He has only sketched his autobiography obliquely; it can be 
pieced together now, by interconnecting poems composed over thirty years. The "dapper salesman" (from "Pop: At Checkers" published in 1967) who was his father was not married to his mother (from "To Sister Mary Apolline" published in 1957), who died in the 1930s when Dana was a child (from "My Glass Brother" published in 1955 and "Blue Run" published in 1984). Dana was left to be raised by others. In a recent poem, he regards a photo of his father, a yellowing snapshot lost for years, now recovered under circumstances left unexplained:

\author{
my mother's \\ lover, hand in pocket, \\ two-tone shoes, a car- \\ maybe the black ' 32 \\ Buick - parked behind him \\ under dusty trees \\ in a dusty lane.
}

The photo is described in a recent poem which begins (and is entitled) "This isn't a story." Is there a story? Is there a lasting narrative? Are there links that endure between persons? These are questions Dana worries incessantly. He would answer them in the affirmative, but indirectly, through the acts that are his poems. As his poems strive to break into open discourse, they become gestures extended to others, continuing a story that is now shared, and expressing a wish that they will endure. 